\title{
病室環境および臨床材料よりの分離緑膿菌 の血清型別と臨床的検討
}

\author{
東大医科研内科 \\ 深谷一太友利玄一
}

\section{まえがき}

近年，何らかの抵抗力減弱を有する患者に括い て, 弱毒菌による種々なる感染症が惹起される例 が注目されている，とくに入院患者に多く，緑膿 菌が各種抗生剂に抵抗性で, 病院内環境によく生 存し，その原因菌となることが知られている。本 間教授 ${ }^{122)}$ により 緑膿菌型別血清 の生産が 確立さ れ，疫学的検討が比較的容易に行ないらることと なり，2，3の報告がみられる。わたしは当院病 室の流し排水口に打ける緑膿菌の消長を観察し， 患者材料よりの分離菌と合わせて種々の検討を行 なつたので，その成績を報告する。

\section{I. 方 法}

1. 病院環境・臨床材料よりの緑膿菌の分離 当院病室扣よび看護婦室の $2 ， 3$ を選び，室内 にある流しの排水口を, 毎週 1 回約 8 力月間隇菌 綿棒で擦過し，N A C 寒天に塗抹し，生育する菌 を Kligler 培地にて分離し，集落の色調から色素 産生の不明瞭な場合は King 培地に接種し，その 産生をたしかめた. 1 平板からはふつら 1 ～2 個 の集落を釣菌した.これらをブイヨンに培養し， ー $20^{\circ} \mathrm{C}$ のディープフリーザーに保存した.

1967年から1970年までに当院検査室に招いて臨 床諸材料から分離された緑膿菌を同様に保存し， 諸検査に供した.

2. 血清型別

本間教授より分与された型別血清 1 〜 13 用 い，型のごとき方法にて施行した.

3. 抗生剂感受性検査

寒天平板法（化学療法学会標準法）により，ス ルフォベンジルペニシリン (SB-PC) 㧊よびカル ボキシベンジルペニシリン (CB-PC) に対する緑
膿菌の感受性值を測定した。

\section{II. 成 績}

1. 病室分離緑膿菌の血清型からみた消長

5 病室の洗面流しの排水口からの分離緑膿菌の 型別の消長を図 1 亿示す. 同一型の菌が一旦検出 されないで再び出現したときは，その中間の部分 を点線で結んで示している．2 個以上を釣菌して 異なつた型の菌をえたときは並記した．各病室の 下段はその時点で入院していた患者の動静を示 す．数カ月にわたつて同一型の菌が続けて証明さ れる例，途中多少の断続を示しつつ長期にわたつ て存在したと考兄られる例などが多くみられた。 一方，一過性の出現も多く遭遇した。 入退院する 患者との関連は不明瞭であつた。しかし，同一患 者が滞留するとさは，分離菌型の安定する傾向が みられるような印象であつた，空室が続いて流し が乾燥すると, 緑膿菌の検出はみられず, 患者入 院後約 1 力月を経過して菌検出が始まつた。 また, 伝染病患者(猩紅熱)の退院後，ホルマリンによる 部屋の消毒を行なつた例では，流しょりの菌検出 飞影響をらけないようであつた。対象とした 5 病 室に和いて，観察期間中に入院患者から 1 例も緑 膿菌感染症の発症をみなかつた. 数回施行した便 培養などに执いても緑膿菌を分離しえなかつた。

同様にして施行した看護婦室の流しに扔ける緑 膿菌血清型別の消長を図 2 に示す。大体に括いて 病室のそれと大差のないものであつたが，むしろ 多彩で, 種々の型の菌が入替わり検出された. ま た， N A C 寒天上に発育する菌数も多いようであ つた.

図 3 は対象とした 5 病室， 3 看護婦室の流しの 全部について，優勢に出現した血清型をシェーマ 
図 1 Course of serotypes of Ps. aeruginosa from each room's sink

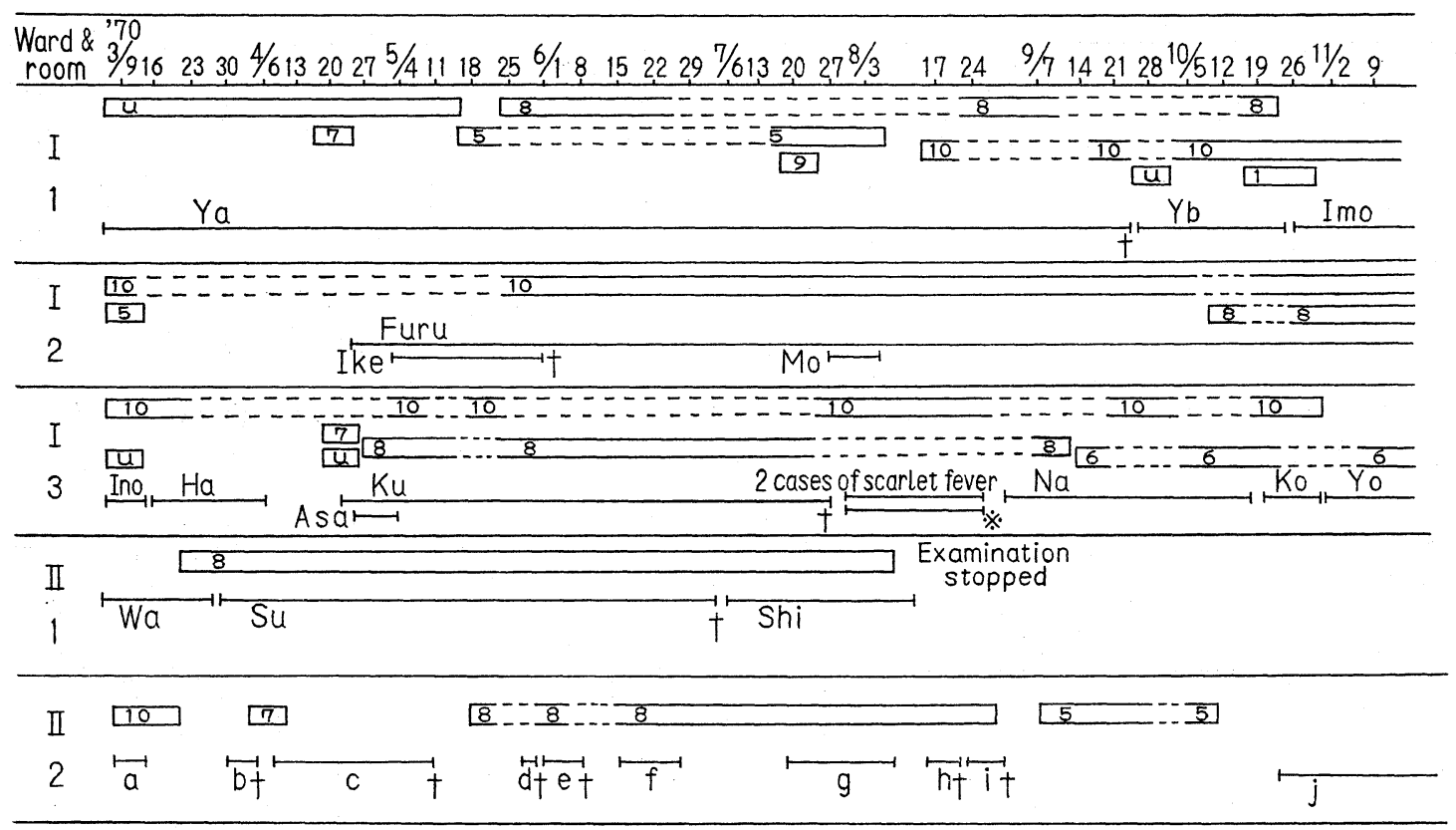

Notes: $\longmapsto$ One case admitted. $※:$ Room was disinfected by formalin gas. $\quad \dagger:$ Patient died. u: untypable

図 2 Course of serotypes of Ps. aeruginosa from sinks of nurse stations

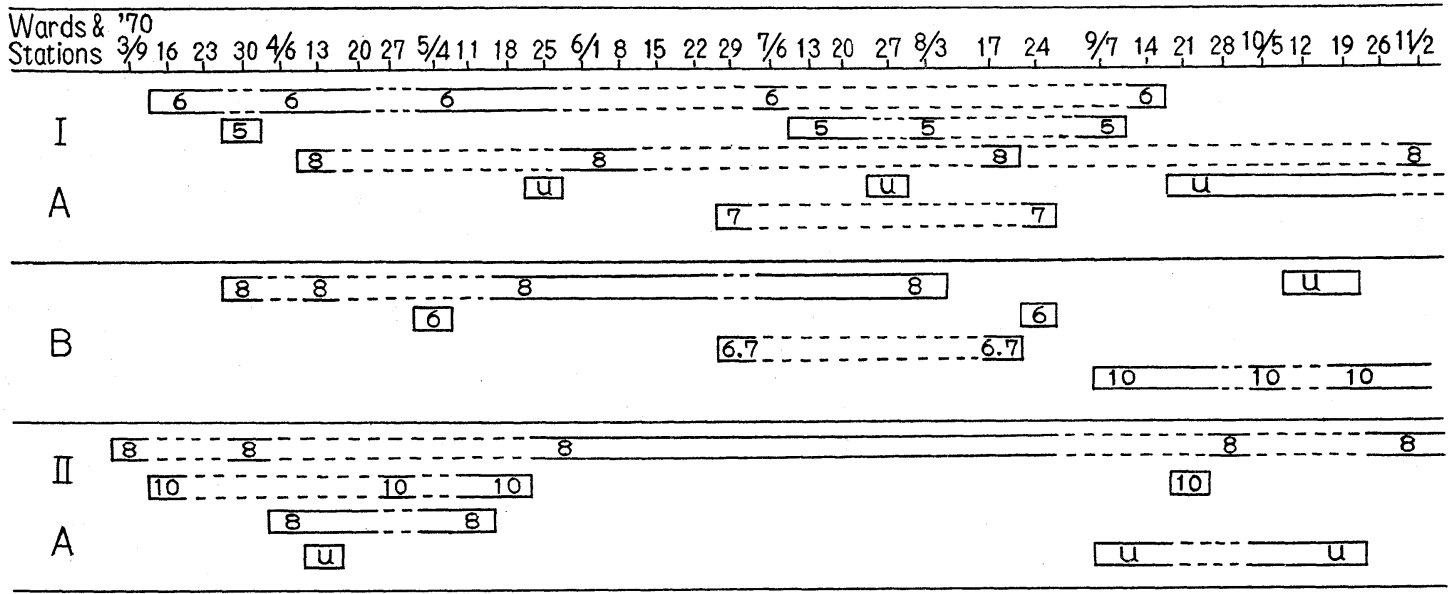

にして示したもので，8型の優位が全体を支配 し，これが各室間へ移り，出現したごとき経過を 示した。 その他，個々に個有の変動を呈している ごとき場合もみられた。

な拈，病院内各所の流しについて同一時期に緑
膿菌の分離を試みたところ，18力所中 8 力所の流 しょり菌を検出し， 8 型が 6 カ所，10，5型が各 1 力所であつて，8 型の普遍的存在が示唆される 成績であつた。

2. 入院患者材料より分離の緑膿菌の血清型別 
表 1 Serotypes of Ps. aeruginosa isolated from sputum of tuberculous patients at the same time (1968.7.12)

\begin{tabular}{|c|c|c|c|c|c|c|c|c|c|c|c|c|c|}
\hline \multirow{3}{*}{ 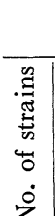 } & & \multicolumn{12}{|c|}{ Serotypes * } \\
\hline & Total & 1 & 2 & 3 & 4 & 5 & 6 & 7 & 8 & 9 & 10 & 11 & 12 \\
\hline & 56 & 12 & 0 & 0 & 5 & 5 & 3 & 4 & 12 & 4 & 7 & 0 & 49 \\
\hline
\end{tabular}

* Each strain was included into plural serotypes, if that strain was agglutinated by two or more antisera.

図 3 Schematic course of main serotypes of Ps. aeruginosa from sinks of wards

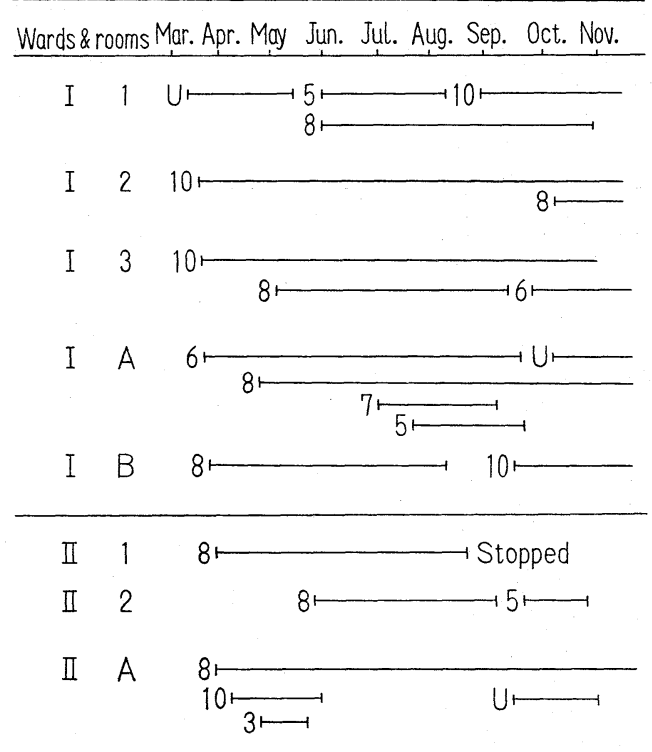

1, 2, 3 : Sick room, A, B : Nurse station

同一時期に結核病棟に入院中の患者喀疢から分 離した緑膿菌56株の血清型の分布は表 1 のごとく で，かなり異つた型の株がひろく分布しているこ とをみとめた。

1967年後半から1970年末むでに病的材料から当 院検査室で分離された緑膿菌の血清型別の年度別 の集計を表 2 に示す．同一人から同型の菌を 2 回 以上分離した場合は 1 回の及数え, 異なつた型の ときはすべて算入して集計した。年度別にみる と, 各血清型について幾分の変遷はみられたが, 通じて $8 ， 10 ， 6 ， 1$ 型などが多く分離され， 2 型は 1 株もえられなかつた. 1968年を頂点として
表 2 Serotypes of Ps. aeruginosa isolated from inpatients

\begin{tabular}{c|c|c|c|c}
\hline Serotypes & 1967 & 1968 & 1969 & 1970 \\
\hline 1 & 1 & 3 & 2 & 3 \\
\hline 2 & 0 & 0 & 0 & 0 \\
\hline 3 & 0 & 1 & 1 & 0 \\
\hline 4 & 1 & 2 & 0 & 0 \\
\hline 5 & 0 & 1 & 3 & 2 \\
\hline 6 & 3 & 3 & 0 & 1 \\
\hline 7 & 0 & 0 & 1 & 4 \\
\hline 8 & 2 & 6 & 6 & 1 \\
\hline 9 & 0 & 1 & 4 & 2 \\
\hline 10 & 3 & 4 & 1 & 4 \\
\hline 12 & 0 & 4 & 0 & 0 \\
\hline $1 . \quad 4$ & 1 & 1 & 0 & 0 \\
\hline $1 . \quad 6$ & 1 & 1 & 0 & 0 \\
\hline $1 . \quad 8$ & 2 & 0 & 0 & 0 \\
\hline 6.8 & 1 & 0 & 0 & 0 \\
\hline $\mathbf{u}$ & 0 & 2 & 3 & 0 \\
\hline Total & 15 & 29 & 21 & 17 \\
\hline
\end{tabular}

分離株数が減少を示している.

これらの分離緑膿菌を, 分離の時期の順序に材 料の由来した病棟別に並べると表 3 のごとくで, 外科病棟では1969 70年にかけて検出株数が増加 し, 反対に内科一般病棟, 結核病棟では減少し, とくに結核病棟からの分離が減少した。これは喀 痰の一般細菌検査の依頼がきわめて減少している ことと関連していると思われる.

外科病棟に执いて1970年度に緑膿菌を分離した 各患者の入院病室 - 入院期間 - 分離菌の血清型に ついての時間的経過は図 4 のごとくで, 各病室 飞括ける伝播といらより, 病棟全体として眺める と, 同じ時期に同じ 7 型または 10 型菌が数名の患 
表 3 Serotypes of Ps. aeruginosa chronologically isolated in each ward

\begin{tabular}{lcccc}
\hline Wards & 1967 & 1968 & 1969 & 1970 \\
\hline Surgical & 10.6 .6 .8 .1$. & 6.6 .10 .3 & $3.9 .1 .9 .9 .10 .1 . u .7$ & 9.1 .7 .1 .7 .7 .7 .10 .10 .5 .10 .6 \\
\hline Medical & 8.10 .6 .6 & 8 & 1 \\
8 & & & \\
\hline
\end{tabular}

図 4 State of patients and serotypes of Ps. aeruginosa isolated from each patient of surgical ward

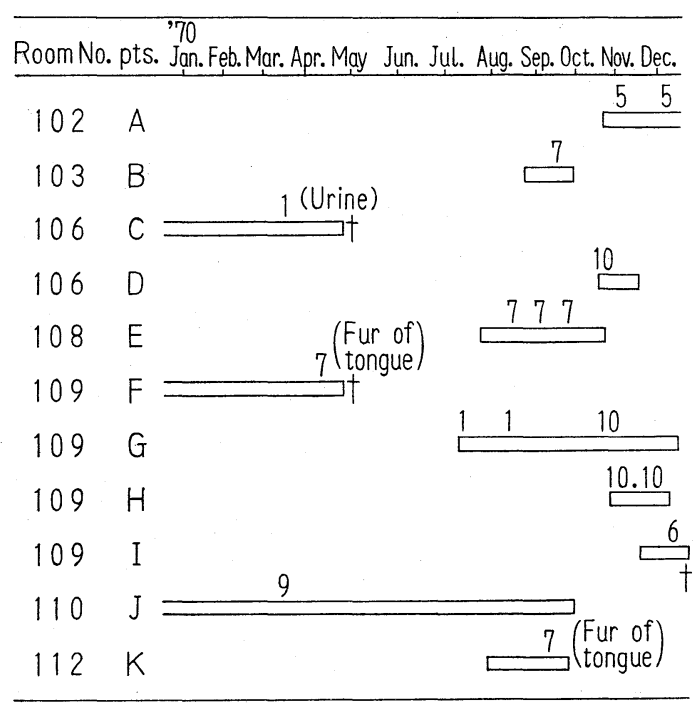

$\square$ : Period of stay in hospital

Source: Pus unless any note. $+\quad:$ died

者から分離されたことが示されている.

3. 実験室的検討

（1）同一平板から 2 個以上釣菌した緑膿菌の 血清型別

検体を塗抹した同一 N A C 寒天平板から 2 個以 上の集落を釣菌し，血清型別を行なつたところ， 2 個拾つた 41回中 29 回 $(70 \%)$ は一致し，12回 （30\%）は互いに相違していた。また，5個釣菌 した10回中， 7 回は 5 個すべて一致したが，残り
の 3 回では 4 個と 1 個， 3 個と 2 個， $2 ， 2 ， 1$ 個の 3 様にそれぞれ別れた。

（2）血清型別不能株の出現頻度

病室流し分離株 263 株中 49 株 $18.6 \%$ が型別不能 であり，臨床材料分離株 42 株中 3 株 $7.1 \%$ が不能 で，流し分離株の方がやや高率であつた. 同一平 板分離株が多数算入されたり，同一流しに型別不 能株が存続し，これらを毎回算入したことも与つ ていよう.

（3）分離緑膿菌の抗生剂感受性

SB-PC に対する緑膿菌の感受性分布を血清型別 に示すと表 4 のごとくで，M I C $100 \mathrm{mcg} / \mathrm{ml}$ を

表 4 Serotypes of Ps. aeruginosa and sensitivity to sulfobenzylpenicillin

\begin{tabular}{c|r|r|r|r|r|r|r|r}
\hline \multirow{2}{*}{ Serotypes } & \multicolumn{5}{|c|}{ MIC mcg/ml } & \multirow{2}{*}{ Total } \\
\cline { 2 - 7 } & $>400$ & 400 & 200 & 100 & 50 & 25 & 12.5 & \\
\hline 1 & & & 2 & 5 & & & & 7 \\
\hline 5 & & 1 & 2 & 4 & 6 & & & 13 \\
\hline 6 & & & & 7 & 2 & & & 9 \\
\hline 7 & 1 & & 1 & 7 & 1 & & & 10 \\
\hline 8 & 3 & 1 & & 9 & 2 & & & 15 \\
\hline 9 & 2 & & 1 & 1 & 1 & 1 & 1 & 7 \\
\hline 10 & 3 & & 3 & 5 & 1 & 1 & & 13 \\
\hline
\end{tabular}

中心に分布した. 同様にして CB-PC に対する M I C の分布を表 5 に示す. 幾分大きい方へ傾い ているが，ほぼ同等の值を示した。これらの表か らM I C $200 \mathrm{mcg} / \mathrm{ml}$ ないしそれ以上を示す緑膿 菌の出現率を血清型別との関連でみると, 表 6 の ごとくで， 6 型菌では耐性菌の出現率が低かつた 
表 5 Serotypes of Ps. aeruginosa and sensitivity to carboxybenzyl penicillin

\begin{tabular}{c|r|r|r|r|r|r|r|r}
\hline \multirow{2}{*}{ Source } & \multicolumn{5}{|c|}{ MIC mcg/ml } & Total \\
\cline { 2 - 7 } & $>400$ & 400 & 200 & 100 & 50 & 25 & 12.5 & \\
\hline 1 & & & 5 & 2 & & & & 7 \\
\hline 5 & & 1 & 2 & 7 & 3 & & & 13 \\
\hline 6 & & 1 & & 6 & 2 & & & 9 \\
\hline 7 & 1 & & 3 & 4 & 2 & & & 10 \\
\hline 8 & & & 7 & 7 & 1 & & & 15 \\
\hline 9 & 1 & & 2 & 1 & $\frac{2}{7}$ & & 1 & $\frac{7}{13}$ \\
\hline 10 & & & 4 & 6 & 3 & & & 13 \\
\hline
\end{tabular}

が，材料のかたより，株数の少なさもあり，一定 の傾向を結論づけえなかつた。

また，病室流し分離株では，MI C $200 \mathrm{mcg} / \mathrm{ml}$ ないしそれ以上を示す株は SB-PC に対し45株中 10株 $(22 \%)$, CB-PC に対し45株中14株（31\%）, 臨床材料分離株では，SB-PC に対し 29株中10株 (34\%)，CB-PC に対し29株中13株（45\%）とな り，いずれも臨床材料分離株の方が病室流し分離 株より耐性を示す傾向がみとめられた。 由来検体 別にみると，SB-PC に対しMI C $200 \mathrm{mcg} / \mathrm{ml}$ な
表 6 Rate of Ps. aeruginosa having MIC of more than $200 \mathrm{mcg} / \mathrm{ml}$ in each serotype

\begin{tabular}{c|c|c}
\hline Serotypes & SB-PC & CB-PC \\
\hline 1 & $2 / 7(29 \%)$ & $5 / 7(71 \%)$ \\
\hline 5 & $3 / 13(23 \%)$ & $3 / 13(23 \%)$ \\
\hline 6 & $0 / 9$ & $1 / 9(11 \%)$ \\
\hline 7 & $2 / 10(20 \%)$ & $4 / 10(40 \%)$ \\
\hline 8 & $4 / 15(27 \%)$ & $7 / 15(47 \%)$ \\
\hline 9 & $3 / 7(43 \%)$ & $3 / 7(43 \%)$ \\
\hline 10 & $6 / 13(46 \%)$ & $4 / 13(31 \%)$ \\
\hline
\end{tabular}

いしそれ以上を示す株は，膿よりの 8 株中 4 株， 痰よりの 10 株中 2 株, 尿よりの 4 株中 2 株, その 他材料 4 株中 2 株 となり，CB-PC でも大同小異 の成績であつた.

（4）緑膿菌の血清型別と由来と色素産生

表 7 に臨床材料分離緑膿菌の血清型別と, 由来 検体との 関連を示す. 8 型が喀痰より多く由来 し，膿汁よりの由来のないことが注目されるが， その他の型ではとくに定まつた傾向はみられない ようであつた。

表 8 は分離緑膿菌の産生する色素の色調と血清

表 7 Serotypes of Ps. aeruginosa and source of strains

\begin{tabular}{l|r|r|r|r|r|r|r|r|r|r|r}
\hline \multirow{2}{*}{ Source } & \multicolumn{7}{c}{ Serotypes } \\
\cline { 2 - 8 } & 1 & 3 & 4 & 5 & 6 & 7 & 8 & 9 & 10 & Others & U \\
\hline Sputum & 4 & & 4 & 3 & 3 & & 10 & 2 & 7 & 5 & 2 \\
\hline Pus & 3 & 1 & 1 & 2 & 3 & 3 & & 3 & 5 & \\
\hline Urine & 2 & & & 2 & & 1 & & 2 & & 3 \\
\hline Others & & & & & & 2 & 1 & & & 2 & 1 \\
\hline
\end{tabular}

$\mathrm{U}$ : untypable

表 8 Serotypes of Ps. aeruginosa and color of pigment formed

\begin{tabular}{l|c|c|c|c|c|c|c|c|c}
\hline \multirow{2}{*}{$\begin{array}{c}\text { Color of } \\
\text { pigment }\end{array}$} & \multicolumn{7}{|c}{ Serotypes } \\
\cline { 2 - 8 } & 1 & 3 & 5 & 6 & 7 & 8 & 9 & 10 & $\mathrm{u}$ \\
\hline Brownish & 2 & 2 & 11 & 5 & 6 & 25 & 2 & 31 & 17 \\
\hline Greenish & 5 & 8 & 3 & 16 & 2 & 35 & 4 & 11 & 17 \\
\hline Light & 2 & 0 & 10 & 3 & 5 & 21 & 2 & 13 & 4 \\
\hline
\end{tabular}


表 9 Source of strains and color of pigment formed

\begin{tabular}{c|c|c|c|c}
\hline \multirow{2}{*}{ Color of pigment } & \multicolumn{4}{|c}{ Source of strains } \\
\cline { 2 - 5 } & Sputum & Pus & Urine & Others \\
\hline Brownish & 3 & 6 & 2 & 2 \\
\hline Greenish & 3 & 4 & 2 & 1 \\
\hline Light & 4 & 4 & 2 & 0 \\
\hline
\end{tabular}

型別との関連をみたものである. 各型の菌が広く 各色調にわかれたが，5型菌は緑色調少なく, 逆 に 6 型菌で緑色調のものが多いよらな数字を示し ているほかには，明瞭な関連はないようであつ た。

表 9 は緑膿菌の由来と色素産生との関連をみた ものであるが，な打例数も少なく，一定の傾向を みとめることはできなかつた。

\section{III. 考 察}

病室流し排水口よりの長期間にわたる定間隔の 検索も，その病室に入院した患者から1例も緑膿 菌感染の症例を見出しえなかつたので，患者と環 境との関連は把握し壳なかつた. この観察で，単 一型の持続もみられたが，型の変動がしばしばみ とめられた.これは, かなり頻繁に緑膿菌の入れ 替わりが起こつていることを示唆している. しか し，各回の釣菌数が少いための見掛け上の現象で あつて, 実際は多種類の血清型の菌が，之の数の 動摇を示しながら共存しているかもしれない.

わたしが以前に結核患者の喀痰の Gram 陰性桿 菌の消長を長期観察したさい, 緑膿菌の検出は, Klebsiella 飞次いで多くみられ，そのさいの型別 を以前に本間教授より分与された型別血清にて行 なつたことがあつた ${ }^{3)}$. このときも今回の流しか らの所見と類似して同一型の持続と, 異つた型の 出没がともにみられたことを経験している.今回 の同一時期に結核病棟入院中の各患者から分離し た緑膿菌の型別がかなり広く分布していた所見も 合致するものである.

本間教授論文 ${ }^{1)}$ に当病院結核患者喀痰の血清型 別の検討成績が記載され，約 3 年の間隔で常に10
型の優勢が認められ，同一型の長期污染が示唆さ れている，わたしの今回の図 1 の成績はその後の ものであるが，やや10型の優位がゆらいでいると いえよう. 病院内各所の流しの一斉検査で，8型 の優勢がみとめられ，次第に変動がみられている のかもしれない，他病院からの報告4)5)とは，抒 のずと異つた成績となつているが，当然のことと 思われる。

外科病棟に持ける同一時期の同一型の検出は, 強く院内伝播を示唆しているといわざるをえな い. 病棟全体としての同一型の分布がみられる点 から，患者間の交流に関与したものとして病院ス タッフの身体の部分，包交用器などを介した伝播 経路が考兄られる.さらに検討を要するところで ある。

緑膿菌の血清型とその他の諸性状との関連につ いては，その相関を示唆したものもあり，尿分離 株は色素産生弱く，5，7型が多いこと，5 型に は色素産生の弱い株が多く，7型治強い株が多 いなどという報告があり ${ }^{4)}$ なた，吉岡ら ${ }^{5)}$ は 5 型には抗生剤低感受性株が多く，8型には高感受 性株が多いとし，5型株は尿由来株が多いため, 感受性の低いことが尿由来のためか型別と関連が あるのか不明としている。 しかし相関を見出し兄 ないとしたものもあり ${ }^{6)}$ ，わたしの今回の検討で も，な拈結論的なことは述べ難いと思われた。血 清型別と関係なく、菌株の由来別に久ると患者よ りの分離株は, 病院環境よりの分離株より抗生剤 耐性の傾向が強く, 差違がみとめられた。菌株蒐 集源が限られているためのかたよりも考兄られ， 結論的なことは差控えたいが，健康人ふ九便より の分離株は病巣分離株より抗生剂感受性が大きい との報告もあり，傾向は同様と考兄られる7?.

緑膿菌感染症の実地臨床に扮いて占める重要性 は近年増加して拉り，抵抗力の減弱した患者に， 新たな力を与えて対処しらる方法を見出すことが 急務と考光る.

\section{IV. 結 論}

1. 当院の 2,3 の病室・看護婦室の洗面流し の排水口から, 滅菌綿棒で擦過し, N A C 寒天培 
地に塗抹することにより，定期的に緑膿菌の分離 を 8 カ月間にわたつて行ない, 分離緑膿菌につい て血清型別を行なつた．一定の型の菌が長期間に わたり分離されることも，2 種以上の型の菌が共 存していることもみられた.

2. 患者分離株についての血清型別を年次別に 集計すると，外科病棟に执いて，同じ時期に数名 の患者から同一型の菌が分離されたことがあり， 院内での伝播を示唆した.

3. 型別された菌について, 血清型と $2 ， 3$ の 抗生剂感受性, 株の由来, 色素産生能などとの関 連を検討したが，とくに明瞭なものは兄られなか つた.

本論文の要旨は第 45 回日本伝染病学会総会において 発表した。

$$
\text { 文献 }
$$

1) 本間 遜，金 桂守，伊藤昌子，山田紘子，塩
野谷博, 河部 靖: 緑膿菌の血清型別と院内感 染, 日本細菌学雑誌, 25 (8) : 379 389, 1970.

2) 本間, 遜 : 緑膿菌感染症一特にその基礎研究の 現状, 感染症学雑誌, 46 (6) : 189 200, 1972.

3) 深谷一太, 北本 治, 金桂守, 本間遜, 坂崎利一: Gram 除性桿菌の長期化学療法患者喀痰上りの 分離にかんする研究, 日本伝染病学会雑誌, 43 (7) : 125 135, 1969.

4) 茂田士郎, 後藤庄助, 石田名香雄: 病院内飞お ける緑膿菌感染症の実態, 臨床病理, 19 (1): $77 \sim 80,1971$.

5) 吉岡 一, 滝本昌俊, 丸山静男, 村山隆志, 古 山正之: 臨床材料から分離された緑膿菌の血 清型と抗生剤感受性について, 感染症学雑誌, 44 (6) : 340 344, 1970.

6) 川上郁：外科に打けるグラム除性桿菌とく 飞緑膿菌に上る感染淿関する研究, 日大医学 雑誌, 30 (6) : 477 505, 1971.

7) 佐竹良夫, 吉岡一, 古山正之, 村山隆志, 上 田京子, 奥平紀子, 林 浪子, 新田克明, 佐藤 清: 緑膿菌の薬剤感受性に関する研究, Chemotherapy 18 (6) : 845 849, 1970.

Serotyping of Pseudomonas aeruginosa Isolated from Sinks of Wards and Patients' Specimens and Its Clinical Investigation

\section{Kazufuto FUKAYA and Genichi TOMORI}

Department of Internal Medicine, Institute of Medical Science, University of Tokyo

The regular isolation of Pseudomonas aeruginosa from the outlet of sinks of several sick-rooms and nurse stations in our hospital wards was performed by the method of scraping with aseptic swab and streaking it on NAC media once a week for 8 months. Sero-typing of strains isolated was also performed, revealing the fact that sometimes the same type has kept isolated for long period, while more than two types happened to be detected concurrently in the other.

Yearly total of serotypes of Pseudomonas strains isolated from clinical specimens suggested that there might have been nosocomial transmission of the same type of Pseudomonas among some inpatients in surgical ward, though in short time duration.

It seemed to be the fact that there was no significant relationship between serotypes of Pseudomonas and sensitivities against a couple of antibiotics, source of strain and pattern of pigment forming. 